\title{
KAJIAN POTENSI BIOAKTIF KANGKUNG LAUT (Ipomea pescaprae) ASAL PESISIR ACEH BARAT SEBAGAI INHIBITOR TIROSINASE DAN ANTIOKSIDAN
}

\section{THE STUDY OF BIOACTIVE COMPOUND POTENTIAL MARINE SPINACH (Ipomea pescaprae) FROM WEST OF ACEH COAST ORIGIN AS TYROSINASE INHIBITOR AND ANTIOXIDANT}

\author{
Eri Safutra ${ }^{1}$, Zuriat $^{2}$ \\ ${ }^{1}$ Jurusan Akuakultur, Fakultas Perikanan dan Ilmu Kelautan, Universitas Teuku Umar, Aceh Barat \\ ${ }^{2}$ Jurusan Perikanan, Fakultas Perikanan dan Ilmu Kelautan, Universitas Teuku Umar, Aceh Barat \\ Korespondensi : Erisafutra@utu.ac.id
}

\begin{abstract}
ABSTRAK
Dewasa ini, begitu banyak inhibitor tirosinase dan antioksidan sintetik yang beredar dipasaran, sehingga konsumen kurang hati-hati dalam melakukan pemilihan produk kosmetik yang menyebabkan terjadinya iritasi kulit dan masalah dermatitis. Hal ini menjadi perhatian bagi para ilmuan untuk mencari solusi alternatif. Tujuan jangka panjang dan terget khusus yang ingin dicapai dari penelitian ini adalah penemuan obat baru yang berasal dari pesisir barat Aceh yang memiliki potensi sebagai inhibitor tirosinase dan antioksidan. Hasil uji fitokimia pada ekstrak daun dan bunga kangkung laut (L pes-caprae) mengandung flavonoid, fenolik dan triterpenoid. Hasil mengenai penentuan aktivitas antioksidan dapat disimpulkan bahwa Ekstrak metanol daun kangkung laut (I. Pes-caprae) memiliki efektifitas sebagai antioksidan dengan nilai absorbansi sebesar $515 \mathrm{~nm}$.
\end{abstract}

Kata Kunci : Ipomea pescaprae, Inhibitor tirosinase, Antioksidan

\begin{abstract}
Nowdays, so many sinthetic tyrosinase and antioxidant inhibitors circulate in the market, so consumers are less careful in choosing cosmetic products that cause skin irritation and dermatitic problems. It is of concern to scientists to seek alternative solutions. The long term objectives and specific targets to be achiaved from this research are the discovery of new drugs originating from the west coast of Aceh which has potential as tyrosinase and antioxidant inhibitors. The results of phytochemical test on leaf watercress and leaf extract (L-caprae) contain flavonoids, phenolic and triterpenoids. Results on the determination of antioxidant activity can be concluded that the extract methanol leaf watercress (I. Pes-caprae) has the effectiveness as an antioxidant with absorbance value of $515 \mathrm{~nm}$.
\end{abstract}

Keywords : Ipomea pescaprae, inhibitor tyrosinase, antioxidant

\section{PENDAHULUAN}

Latar belakang

Ipomea pescaprae merupakan tumbuhan

liar yang hidup berkembang di daerah pantai yang tanahnya berbatu-batu dan mengandung pasir. Tumbuhan pantai banyak tersebar di daerah pesisir Aceh Barat. Secara umum penggunaan obat tradisional yang digunakan di Indonesia merupakan jamu-jamuan yang berasal dan tumbuh yang hidup dipesisir laut seperti bakau, dan umbuhan pesisir. Salahsatu contoh tumbuhan pesisir adalah katang-katang (Ipomea pescaprae). Katang-katang telah di kenal secara luas oleh masyarakat kita sebagai obat reumatik / nyeri persendian, myalgia (sakit otot/pegal-pegal), pendarahan pada wasi, pembengkakan gusi dan sakit gigi, sedangkan Bandaranayake (2002) mengatakan bahwa tumbuhan katang-katang merupakan tumbuhan obat yamg telah digunakan

\footnotetext{
${ }^{1}$ Fakultas Perikanan dan Ilmu Kelautan, Universitas Teuku Umar

Korespondensi : Jurusan Akuakultur, Fakultas Perikanan dan Ilmu Kelautan, Universitas Teuku Umar, Kampus UTUMeulaboh, Alue Peunyareng 23615, Telp: +62 81281861746, email: erisafutrautu.ac.id
} 
diberbagai negara untuk mengobati penyakit seperti peradangan yang meliputi dermatitis akibat sengatan ubur-ubur. Katang-katang dikenal dengan nama lokal yang berbeda-beda seperti tangkatang, daun katang alere, leleri, dalere, batata pantai, tapak kuda, andah arana, daredai, wal 80 ruruan, dolodoi, tilalade, mari-mari, wacuv, ıatiraui, ngamir, loloro, bulalingo, wedule, ma an teng (China) (BPPT, 2005).

T. Ramanathan et al ( 2012 ) melaporkan bahwa daun katang-katang dipesisir India berpotensi sebagai anti oksidan dan penangkap radikal bebas. Hal ini melandasi keingin tahuan peneliti untuk mengkaji lebih lanjut dalam ekslporasi senyawa bioaktif daun dan bunga katang-katang (Ipomea pescaprae) yang memiliki potensi inhibitor tirosinase dan antioksidan. Kajian tentang aktifitas antioksidan penting dilakukan untuk membuktikan secara scintifik apakah tumbuhan katang-katang (Ipomea pescaprae) mempunyai kemampuan dalam menangkap radikal bebas (free radical).

\section{METODE PENELITIAN Waktu dan tempat}

Pelaksanaan penelitian ini dilakukan mulai bulan Juni sampai dengan September 2017. Prosedur penelitian dimulai dari pengambilan sampel Ipomea pescaprae dipesisir laut Aceh Barat, sampel kemudian diidentifikasi dan dideposit untuk memperoleh voucher number di Fakultas Pertanian Universitas Syiah Kuala (UNSYIAH) dan sebagian pengujian dilakukan di Pusat Studi Biofarmaka IPB Bogor.

\section{Alat dan bahan}

Alat dan bahan yang digunakan pada penelitian ini disajikan pada Tabel 1 dan Tabel 2

Table 1 Alat yang digunakan dalam penelitian

\begin{tabular}{|c|c|c|}
\hline No & Alat & Fungsi \\
\hline 1 & Rotary Evaporator & Memisahkan bahan terlarut dengan bahan pelarut \\
\hline 2 & Labu Erlemeyer & Menyimpan bahan kangkung laut \\
\hline 3 & Tabung Reaksi & Menyimpan bahan \\
\hline 4 & Gelas Ukur $100 \mathrm{ml}$ & Mengukur bahan \\
\hline 5 & Pipet Tetes & Menyemprotkan bahan \\
\hline 6 & Rak Tabung & Menempatkan tabung reaksi \\
\hline 7 & Pisau & Menghaluskan bahan \\
\hline 8 & $\begin{array}{l}\text { Kertas Saring Whatman } \\
\text { No. } 42\end{array}$ & Menyaring bahan kangkung laut \\
\hline 9 & $\begin{array}{l}\text { Timbangan Analitik } \\
0,01 \text { gr }\end{array}$ & Menimbang bahan \\
\hline 10 & Auto Clave $121^{\circ} \mathrm{C}$ & Mensterilkan alat \\
\hline 11 & Hot Plate & Memanaskan media Na dan kangkung laut \\
\hline 12 & Pinset & Mengambil bahan \\
\hline 13 & Magnetic Strrier & Mempercepat pemisahan bahan \\
\hline
\end{tabular}

Tabel 2. Bahan yang digunakan dalam penelitian

\begin{tabular}{cll}
\hline No & \multicolumn{1}{c}{ Bahan } & \multicolumn{1}{c}{ Fungsi } \\
\hline 1 & Kangkung laut & Bahan uji \\
2 & Larutan $\mathrm{FeCl}_{3} 1 \%$ & Mempercepat reaksi \\
3 & $\mathrm{HCl} \mathrm{0,5 \%}$ & Pengenceran \\
4 & Asam klorida 5\% & Menstandarisasi larutan natrium
\end{tabular}


5 Aquades

6 Etanol $70 \%$

$7 \quad \mathrm{NaCl} 0,9 \%$

8 Tissue
Pelarut non polar

Pelarut polar

Mengganti cairan plasma isotonik

Untuk membersihkan

\section{Prosedur penelitian}

Bagian tanaman lalu dipisahkan antara bagian daun dan bunga. Setelah itu, tiap bagian dikeringkan dan dibuat dalam bentuk serbuk dan dilakukan penentuan kadar air dan abu. Serbuk diekstraksi secara bertingkat dengan cara maserasi dimulai dengan pelarut non polar (aseton) kemudian di ekstraksi kembali dengan pelarut semipolar (etilasetat), dan terakhir di ekstraksi dengan pelarut polar (metanol). Semua ekstrak yang dihasilkan diuji fitokimia, aktifitas antioksidan, penentuan kandungan total fenol, flavonoid dan tanin dilakukan dengan menggunakan spektrofotometer UV-Visible dan kemudian di analisis korelasi total fenolik, flavonoid, tanin dengan antioksidan.

Prosedur Preparasi dan Ekstraksi Sampel

Preparasi sampel ekstrak Ipomea pescaprae dilakukan dengan cara mengeringkan sample daun katang-katang, kemudian dibuat serbuk. Sampel kering berupa serbuk kemudian ditentukan kadar air dan kadar abu, lalu dilakukan ekstraksi secara bertingkat dengan cara maserasi dimulai dengan pelarut non polar (kloroform) dan ampas yang diperoleh kemudian di maserasi kembali dengan pelarut semi polar (etilasetat) dan terakhir ampas diekstraksi dengan pelarut polar (metanol). Semua ekstrak yang diperoleh disaring dengan menggunakan kertas saring dan dipekatkan dengan penguap putar pada suhu $30{ }^{\circ} \mathrm{C}$ kemudian rendemen tiap ekstrak dihitung (Batubara et al, 2010).

Bahan yang digunakan adalah daun dan bunga Ipomea pescaprae yang diperoleh dari pesisir laut Aceh Barat yang terdiri dari daun dan bunga. Bahan kimia yang digunakan yaitu metanol p.a, etanol p.a, etil asetat, $\mathrm{HCl}$, kloroform, dietil eter, n-heksan, DMSO (dimetilsulfoksida), akuades, buffer fosfat $\mathrm{pH}$ 6.5, larutan L-tirosin, L-DOPA, enzim tirosinase (Sigma 333 unit/ml dalam buffer fosfat), larutan 2,2-difenil-1-pikrihidrasil (DPPH). Asam askorbat (vitamin C). Alat-alat yang digunakan adalah spektrofotometer UV-VIS (Brucker), multiple well plate reader (ELISA), multiwell plates, oven, tanur, eksikator, hot plate, neraca analitik (Sartorius) rotavapor putar, sudip, rak tabung reaksi, vortex, sarung tangan, tabung reaksi, gelas piala, pipet mohr, pipet volumetrik, pipet mikro cawan petri, cawan porselin danlabu takar $(5 \mathrm{ml}$ dan $250 \mathrm{ml}$ ).

1. Uji Fitokimia

Uji fitokimia merupakan uji pendahuluan untuk mengetahui kandungan senyawa spesifik alkaloid, triterpenoid, streroid, saponin, flavonoid, kuinon, tanin dan fenol secara kualitatif (Harbone, 1987).

2. Uji aktivitas antioksidan

Metode Penangkapan Radikan Bebas DPPH

Metode DPPH yang digunakan pada tahap ini berdasarkan dari metode yang telah dilakukan oleh Batubara et al (2009), sampel dilarutkan dalam etanol sehingga diperoleh konsentrasi akhir 1.67, $3.33,6.67,10.00,13.33$, $16.67,33$ 33,66.67,66.67,100.00,133.33, dan 166.67 $\mu \mathrm{g} / \mathrm{ml}$. Pada $100 \mu \mathrm{l}$ sampel, kemudian ditambahkan $100 \mu$ l larutan DPPH (1.18 $\mathrm{mg}$ DPPH dalam $10 \mathrm{ml}$ etanol (pada masing-masing lubang well plate. Setelah 30 menit absorbansi diukur pada $517 \mathrm{~nm}$. Kontrol positif yang digunakan adalah asam askorbat, dan etanol sebagai blangko. Setiap konsentrasi sampel dan kontrol positif diuji dua kali pengulangan. Persentase inhibisi dihitung berdasarkan persamaan :

$\%$ inhibisi $=[1-(\mathrm{A}$ sampel - Akontrol $) / \mathrm{A}$ Blangko-Akontrol)] x $100 \%$

Keterangan :

A sampel adalah absorvasi sampel

A kontrol adalah absorbansi asam askorbat

A blangko adalah absorbansi etanol

Nilai konsentrasi hambat 50\% (IC50) ditentukan 
dengan menggunakan persamaan regresi linier yang menyatakan hubungan antara konsentrasi sampel uji (sebagai sumbu $\mathrm{x}$ ) dan persentase inhibisi (sebagai sumbu y).

\section{2 is Data}

Uj1 ANOVA (Steel dan Torrie 1993)

Data selanjutnya dianalisis menggunakan model rancangan ANOVA (Analysis of Variant) dengan formulasi Steel \& Torrie (1993). Rancangan yang digunakan adalah Rancangan Acak Lengkap (RAL). Analisis RAL atau ANOVA (One Way Factor) menggunakan software IBM SPSS Statistic version 22. Model persamaan RAL adalah sebagai berikut:

\section{Keterangan:}

Yij = Nilai pengamatan pada taraf $\mathrm{i}$ ulangan ke-j $\mathrm{p},=$ Nilai tengah atau rataan umum pengamatan $\mathrm{Ti}=$ Pengaruh perbedaan jenis ekstrak dan konsentrasi ekstrak metanol pada taraf ke-i $(\mathrm{i}=1,2,3)$

eij $=$ Galat percobaan pada konsentrasi taraf ke-i dengan ulangan ke-j

Hipotesa rancangan acak Lengkap (RAL) aktivitas antioksidan ekstrak sampel adalah sebagai berikut:

Ho : konsentrasi yang berbeda tidak

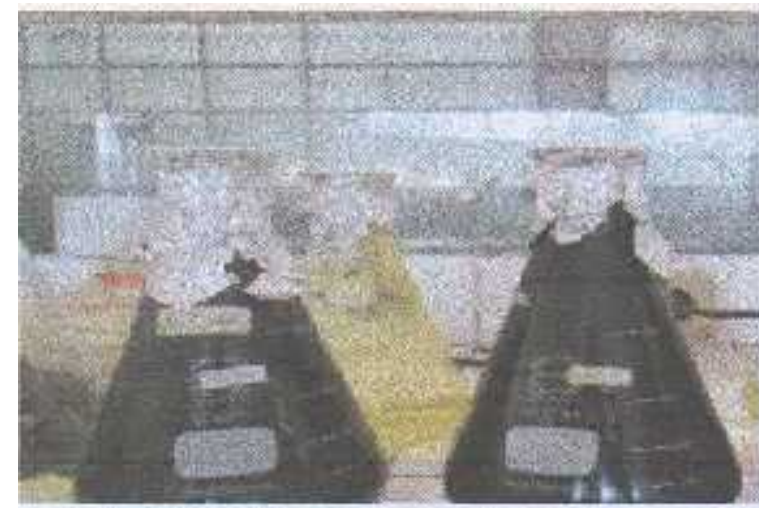

Gambar 1. Ekstraksi Daun Kangkung Laut (I. Pes-caprae) dengan dua pelarut (a) Metanol, (b) Etil asetat.

Hasil maserasi sebanyak 500 gram daun kangkung laut dengan pelarut metanol diperoleh ekstrak cair berwarna coklat pekat dan setelah dipekatkan menjadi coklat tua, ekstrak kasar yang berwarna hijau muda dengan pelarut etil asetat diperoleh ekstrak cair berwarna hijau tua bunga kangkung laut sebanyak 440 gram dan setelah dipekatkan menjadi ekstrak kasar berwarna coklat. Sementara maserasi diperoleh ekstrak cair berwarna coklat dan setelah dipekatkan menjadi ekstrak cair berpengaruh nyata terhadap aktivitas antioksidan.

$\mathrm{H}_{1}$ : konsentrasi yang berbeda berpengaruh nyata terhadap aktivitas antioksidan.

\section{Uji Duncan}

Uji Duncan dilakukan ketika hasil dari pengujian ANOVA menunjukkan adanya pengaruh yang berbeda nyata pada selang $95 \%(\mathrm{a}=0,05)$. Hasil yang berbeda nyata tersebut dilakukan uji lanjut Duncan.

\section{Hasil dan Pembahasan}

\section{Ekstrak Daun Kangkung Laut (Ipomea pes- caprae)}

Hasil ekstraksi daun dan bunga kangkung laut (Ipomea pescaprae) dengan menggunakan pelarut metanol 98\% diperoleh ekstrak cair berwarna coklat tua dan menggunakan etil asetat 96\% diperoleh ekstrak cair berwarna hijau muda kemudian dievaporasi menggunakan rotary evaporator 82

leh ekstrak kasar berwarna hijau tua. 


\section{Uji Fitokimia}

Analisis fitokimia merupakan salah satu cara untuk mengetahui kandungan metabolit sekunder pada suatu sampel (Harborne, 1987). Analisis ini sangat berguna untuk menentukan golongan utama senyawa aktif dari ekstrak daun dan bunga kangkung laut (L pes-caprae) memiliki potensi sebagai inhibitor tirosinase dan antioksidan. Uji yang dilakukan meliputi uji steroid, flavonoid, fenolik, triterpenoid, dan alkaloid. Berdasarkan uji fitokimia pada ekstrak daun dan bunga kangkung laut (L pes-caprae) mengandung flavonoid, fenolik dan triterpenoid. Adapun hasil pengujian fitokimia ekstrak daun kangkung laut (I pescaprae) ditunjukkan pada Tabel 3.

Tabel 3. Hasil analisis fitokimia ekstrak kasar daun kangkung laut pes-caprae)

\begin{tabular}{cc}
\hline Identifikasi & Flavonoid \\
Senyawa & \\
\hline
\end{tabular}

\begin{tabular}{lc} 
Aseton & +++ \\
Etil Asetat & +++ \\
Metanol & +++ \\
\hline
\end{tabular}

Keterangan : +: kurang pekat, ++: sedang dan +++ : pekat.

Berdasarkan Tabel 3, menunjukkan bahwa filtrat ekstrak daun kangkung laut (I. P escaprae) dengan menggunakan pereaksi metanol menunjukkan adanya flavonoid dan fenolik dengan kisaran pekat, sedangkan senyawa triterpenoid berada pada kisaran sedang. Triterpenoid nampak jelas ketika ada warna merah pada saat filtrat uji Lieberman. Untuk memperoleh hasil inhibitor tirosinase dan antioksidan penting sebagai zat penghamba(t reaksi oksidasi akibat radikal bebas. Tanaman daun kangkung laut I.pescaprae) memiliki aktivitas tirosinase dan antioksidan, yang mengandung senyawa dan mampu menangkal radikal bebas yaitu flavonoid dan fenolik.

\section{Aktivitas Antioksidan Metode DPPH}

Pengujian aktivitas antioksidan dalam daun dan bunga kangkung laut (I.pescaprae) dilakukan menggunakan metode DPPH (1,1 diphenil-1pikrilhidrazil) yang memiliki rumus molekul C13H12N04 (Sletty, 2004 dalam Molyneux, 2006), suatu radikal bebas stabil yang dapat bereaksi dengan radikal lain membentuk senyawa yang lebih stabil. Radikal bebas DPPH merupakan radikal sintetik yang stabil pada suhu kamar dan larut dalam pelarut polar seperti metanol dan etil asetat (Suratmo, 2009). Delokalisasi ini akan memberikan wal 83 igu gelap dengan absorbansi maksimum $5151^{83}$ am larutan metanol dan etil asetat (Umiyah, 2005 dalam Rita, 2009) seperti Gambar 2 dibawah ini.

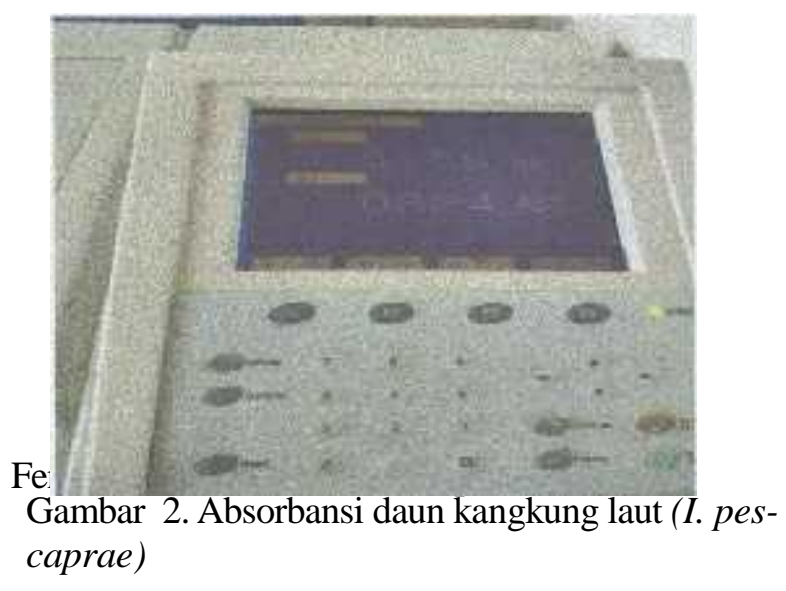

Konsentrasi ekstrak daun dan bunga kangkung latit yang digunakan pada metode DPPH ini adalah 24,\$8,32,36, dan 40 ppm. Kensentrasi tersebut diperoleh dari pengenceran stok ekstrak dengan konsentrasi 160 ppm, sepeti terlihat pada Gambar 3 dibawah ini.

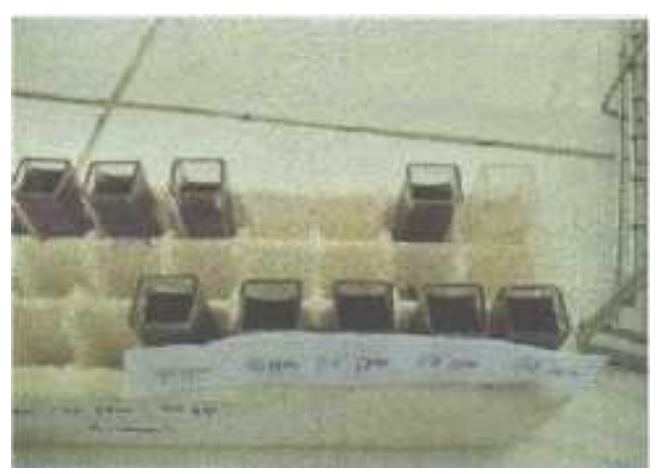

Gambar 3. Konsentrasi daun 24,28,32,36, dan 40 ppm.

Aktivitas antioksidan dengan metode menunjukkan bahwa ekstrak daun dan bunga kangkung laut (I. Pes-caprae) dengan filtrat mempunyai nilai tertinggi pada pelarut ekstrak etil asetat daun kangkung laut dengan nilai rerata sebesar 3,749, kemudian diikuti oleh ekstrak metanol bunga kangkung laut memiliki nilai rerata sebesar 3,509. Hasil lengkapnya disajikan pada Tabel 4. 
Tabel 4. Nilai absorbansi ekstrak metanol dan etil asetat, daun kangkung laut ( I. pes-caprae).

\begin{tabular}{|c|c|c|c|}
\hline Sampel & Konsentrasi (ppm) & Absorbansi & Rerata \\
\hline \multirow{5}{*}{ Vit C/Asam } & 24 & 0,020 & \multirow[b]{5}{*}{0,0118} \\
\hline & 28 & 0,014 & \\
\hline & 32 & 0,011 & \\
\hline & 36 & 0,008 & \\
\hline & 40 & 0,006 & \\
\hline \multirow{5}{*}{$\begin{array}{c}\text { Ekstrak metanol } \\
\text { daun kangkung } \\
\text { laut }\end{array}$} & 24 & 0,769 & \multirow[b]{5}{*}{3,435} \\
\hline & 28 & 0,719 & \\
\hline & 32 & 0,705 & \\
\hline & 36 & 0,628 & \\
\hline & 40 & 0,614 & \\
\hline \multirow{5}{*}{$\begin{array}{c}\text { Ekstrak etil asetat } \\
\text { daun kangkung } \\
\text { laut }\end{array}$} & 24 & 0,843 & \multirow[b]{5}{*}{3,749} \\
\hline & 28 & 0,741 & \\
\hline & 32 & 0,733 & \\
\hline & 36 & 0,724 & \\
\hline & 40 & 0,708 & \\
\hline
\end{tabular}

Batubara I, Mitsunaga T, Ohashi H. 2009. Screening anti-acne potency of Indonesia medicinal

\section{KESIMPULAN}

Kesimpulan

Berdasarkan hasil penelitian mengenai penentuan aktivitas antioksidan dapat disimpulkan bahwa Ekstrak metanol daun kang,kung laut (I. Pes-caprae) memiliki efektifitas sebagai antioksidan dengan nilai absorbansi sebesar $515 \mathrm{~nm}$.

\section{DAFTAR PUSTAKA}

Backer dan Van Den Brink Jr. RCB. 1963. Flora of Java. Vol 1, Netherlands: Auspices of the Rusksherbarium. NVP. NoordhoffGronigen.

Bandaranayake WM. 2002.Bioactivities, bioactive compounds and chemical of mangrove plants. Wood Ecosystem Mangrove. 10:421-452. plants: Antibacterial, lipase inhibition and Antioxidant activities. Journal Wood Science. 55: 230-235.

Batubara I, Darusman LK, Mitsunaga T, Rahminiwati M, Djauhari E. 2010.Potency of indonesia medicinal plants as tyrosinase inhibitors andantioxidant agent. Journal Biological Science 10(2): 138-144.

BPPT. Badan Pusat Penelitian Tanaman, Tanaman Obat Indonesia. 2005. Tapak Kuda (Ipomea pes caprae) (L.J.Sweet). http://www.IPTEK.

Chakraborty AK, Funasaka Y, Komoto M, Ichihashi M. 1998. Effect of arbutin on melanogenic proteins in human melanocytes. Pigment. Cellular. Research. 11 : 206-212. 
Chang TS. 2009. An updated review of tyrosinase inhibitor. International Journal Molecule Science. 10: 2440-2475.

Devall M.S. 1992. The biological flora of coastal dunes and wetlands. Ipomea pes caprae $(\mathrm{L})$ Roth. Journal of coastal Research 8 (2) : $442-456$.

Dimitrios B. 2006. Sources of natural fenolic antioxidants. Trends in Food Science and Technology. 17: 505-512.

Dorland, Newman W.A. 2000. Dorland's ilustrated Medical Dictionary. Philadelphia: pennsylvania. W.B. Saunders Company.

Edward F. 1999. Ipomea pes caprae. University of Florida. Cooperative Extension Service. Institute of Food and Agricultural
Sciences.

Gilchrest. 1998. Turning back the clock: retinoi 85 modifies intrinsic aging changes. Jour...., , Clinical. Investment. 94 : 1711-1712.

Harborne JB. 1987. Metode fitokimia. penuntun cara modern menganalisis tumbuhan. Bandung: ITB press. Terjemahan Kosasih Padmawinata.

Hardjito L, Kingston D. 2004. Laporan RUTI 2004. Bioactive Compounds from Indonesia marine invertebrata and their sustainable Production Through Maricultured. Penelitian DIKTI.

Kahn V Ben-Shalom N, Zakin V. 1997. Effect of Kojic Acid on the Oxidation of $\mathrm{N}$ Acetyldopamine by mushroom. Journal of Agricultural Food Chemistry. 45 ; 44604465.

Khazali M, Suryadiputra, Yus Rusila Nur. 1999. Panduan Pengenalan Mangrove di Indonesia. Bogor : Ditjen PKA. 